\section{Work for revision in geomorphology}

Peter Worsley

Geomorphology of Europe.

Edited by Clifford Embleton.

Macmillan Press, London: 1984.

Pp.465. Hbk £45; pbk £17.50.

THE publication of Geomorphology of Europe raised hopes that at last there would be a European equivalent to W.D. Thornbury's Regional Geomorphology of the United States, or perhaps C.B. Hunt's splendid Natural Regions of the United States and Canada. In the event the overall impression is one of disappointment, of a work which has failed to fulfil its potential.

The book was originally conceived as a text to complement the International Geomorphological Map of Europe, a project undertaken by the International Geographical Union. The map is as yet incomplete and the book became "a work in its own right", able to stand independently of the forthcoming map. Any critique is naturally deflated to some extent when it is declared that "the editor is well aware of shortcomings in the work and of uneveness of treatment"'. Indeed one can fully sympathize with the demanding task of managing contributions by some 24 different authors from about ten nations. Apart from the occasional lapse into unfamiliar terminology, Professor Embleton and his Czech colleague Jaroslav Dernek have done wonders in producing a linguistically well-written text.

However one cannot altogether excuse the admitted variability in detail simply because the level of knowledge from region to region is uneven. At the level of generalization appropriate in a work dealing with an entire continent, it ought to be possible to achieve greater uniformity. Further, that "no attempt has been made to standardize the contributions from different authors" is surely a recipe for trouble.

All of the chapters are organized on the basis of structural subdivisions of the continental areas, except for two which deal with the now-submerged shelf. Such an approach is sound but does entail some unfamiliar division of the material; for example the British Isles are discussed in three separate chapters (Caledonian Highlands, West and Central European Highlands, and Hercynian Europe). Within each structural unit summaries are given of the geology, Cenozoic landscape evolution, Quaternary history and coastal character (where relevant), sometimes with comments on contemporary processes. Clearly the newer, climatically influenced geomorphological features do not fit readily into a structural framework but we must recognize the dilemma created by the need to deal with the entire scope of geomorphology. The greatest benefit from the book will be derived by those who require a briefing on an unfamiliar part of Europe. This would have been aided by the inclusion of key bibliographic citations at the end of each chapter, enabling the reader to quickly identify the main sources available. For instance one is astonished to find no mention in the treatment of England of C.A.M. King's Northern England nor A. Straw and K.M. Clayton's Eastern and Central England, both of which are extremely valuable guides to the literature.

A close knowledge of each of the various regions is of course necessary to identify inaccuracies. With reference to Britain, we find a strict adherence to a Quaternary framework established over a decade ago, with no hint that this sequence is incomplete or indeed that additional stages have now been defined. The generally jaded flavour is also apparent, for example, in the apparent oblivion to the substantial evidence assembled by $\mathrm{J}$. Boardman for a pre-Devensian glaciation of the Lake District or to J.B. Sissons's penetrating work on the Loch Lomond Stadial cirque glaciation in the same area. One is curious to know where the claimed 300 -m-thick crag sequence is located in East Anglia, or where Pliocene crags are subject to rapid coastal erosion, or what is the evidence for a Beestonian sea level of $-100 \mathrm{~m}$. In the south-west of England consideration of the important Tertiary Petrockstow Basin is omitted, as it is of the allied major wrench fault which crosses the entire peninsula.

Even less excusable is the poor quality of the illustrations. Many of the maps are reproduced at an inappropriate size (usually too large), the lettering is frequently crude and generally they appear amateurish. Monochrome photographs are dispersed throughout the text, but while some are successful many are badly reproduced. Printing problems apart, the selection of the photographs appears to have been haphazard, many being of dubious value. Perhaps the prize in this respect goes to Fig. 9.36, "Planation surface, probably etchplain with peat cover", which is devoid of any scale and impossible to interpret. The statutory (these days) satellite images are restricted to France and Central Europe and their definition is so poor they serve no useful purpose.

Regrettably, therefore, it is difficult to avoid the verdict that this is a work in need of revision. Such a conclusion is frustrating since the overall objectives are admirable and there is a real need for a synthesis of European geomorphology. This book is a step in the right direction but is, alas, an unsatisfactory first attempt at filling the gap.

Peter Worsley is Professor of Physical Geography at the University of Nottingham.

\section{Gatekeepers of the chemical cycles}

\author{
J. M. Hayes
}

Microbial Geochemistry.

Edited by W.E. Krumbein.

Blackwell Scientific: 1984. Pp. 330.

$£ 35, \$ 59.95$.

THE ocean, about as old as the planet itself and the place of origin of nearly all sedimentary rocks, is one of the main reaction vessels for the processes of global chemistry. Some of the most important actors on that grand stage are microscopic in size. Though each individual works on a scale absurdly small in proportion to the environment, unicellular organisms effectively control the marine chemistry of many elements. Further, bacteria living in the mud and ooze of the ocean floor commonly have the last word before constituents of sediments are more or less immobilized by the process of lithification.

There are fascinating - and still largely uninvestigated, let alone answered questions regarding the possible importance of bacterial processes in sediments at depths of kilometres and over times familiar to geologists but not microbiologists. In any event, microorganisms again play important roles as the rock cycle is closed by processes including uplift and

\section{Bring Your Library Up-To-Date With This ANS Edition...}

\section{J.M. Cleveland MONOGRAPH}

\section{The Chemistry Of Plutonium}

\author{
Approx. 680 pages $6 " \times 9 "$ \\ Hardbound $\$ 49.00$
}

\section{American Nuclear Society 555 North Kensington Avenue La Grange Park, IL 60525 USA}

Please take my order for __ book(s).
$\square$ Payment in full enclosed.
$\square$ Bill me and I accept postage and
handling charges.
Name
Organization
Street
City
State Z Zip

